\title{
Phenotypic variation of lipid composition in Burkholderia cepacia: a response to increased growth temperature is a greater content of 2-hydroxy acids in phosphatidylethanolamine and ornithine amide lipid
}

\author{
Catherine J. Taylor, ${ }^{1,2}$ Alistair J. Anderson ${ }^{2}$ and Stephen G. Wilkinson ${ }^{1}$
}

Departments of Chemistry 1 and Biological Sciences', University of Hull, Hull HU6 7RX, UK

\author{
Author for correspondence: Stephen G. Wilkinson. Tel: +44 1482 465484. Fax: +44 1482466410. \\ e-mail: S.G.Wilkinson@chem.hull.ac.uk
}

Keywords: Burkbolderia cepacia, lipids, phenotypic variation, 2-hydroxy acids

\section{INTRODUCTION}

Burkbolderia cepacia is now recognized as a significant opportunistic pathogen, particularly in relation to cystic fibrosis (Govan \& Deretic, 1996; Govan et al., 1996). In consequence, considerable effort has been expended on the study of potential virulence factors (Nelson et al., 1994; Wilkinson \& Pitt, 1995b) and on methods of strain characterization for use in epidemiological investigations (Wilkinson \& Pitt, 1995a). One of the most striking features of the surface chemistry of the organism is the range of polar lipids, which includes two forms each of phosphatidylethanolamine (PE) and

Abbreviations: DPG, bis(phosphatidyl)glycerol; $O L$, ornithine amide lipid; PE, phosphatidylethanolamine; PG, phosphatidylglycerol; PHB, poly(3-hydroxybutyrate). ornithine amide lipid (OL), differing in the presence or absence of an ester-linked 2-hydroxy fatty acid (Kawai et al., 1988b; Cox \& Wilkinson, 1989), as well as phosphatidylglycerol (PG) and/or bis(phosphatidyl) glycerol (DPG) and an uncharacterized glycolipid (Yabuuchi et al., 1992). OL consists of various molecular species based on the general $\alpha-N$-acyloxyacylornithine structure (1) applicable to such lipids in diverse bacteria (Wilkinson, 1988).

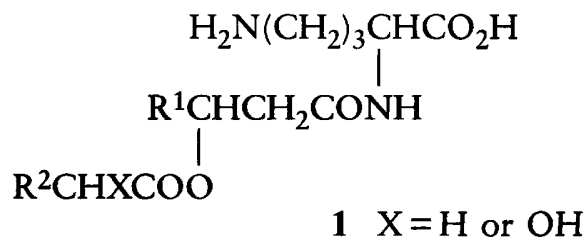


This unusual lipid profile for B. cepacia is characteristic of other Burkbolderia spp. (Galbraith \& Wilkinson, 1991; Yabuuchi et al., 1992; Phung et al., 1995a), whereas certain species recently excised from Burkbolderia and Alcaligenes to form the new genus Ralstonia lack both forms of OL (Galbraith \& Wilkinson, 1991; Yabuuchi et al., 1995). Phenotypic variation of lipid composition in bacteria, including the stimulation of $\mathrm{OL}$ production by growth under phosphorus-limiting conditions for at least some Gramnegative species, is a well-known phenomenon (Wilkinson, 1988). Also, by virtue of its amphiphilicity and endotoxin-like structure, OL possesses various biological activities, including haemagglutination, macrophage activation, hypothermic response and adjuvanticity (Kawai \& Yano, 1983; Kawai \& Akagawa, 1989; Kawai et al., 1996; Kato \& Goto, 1997). Thus to confirm the chemotaxonomic value and evaluate any pathogenic potential of these lipids, it was desirable to verify that the profile was a stable characteristic of Burkholderia spp. and to identify any effects of growth parameters on the lipid profile. The wellstudied strain NCTC 10661 of B. cepacia was selected for this purpose.

\section{METHODS}

Organism and growth conditions. B. cepacia strain NCTC 10661 was grown in continuous culture using a chemostat $(1 \cdot 5$ 1) and a chemically defined medium (CDM) with succinate as the source of carbon. In studies of the effects of growth temperature, carbon was the growth-limiting nutrient in a CDM of the following composition $\left(\mathrm{g} \mathrm{l}^{-1}\right): \mathrm{MgSO}_{4} \cdot 7 \mathrm{H}_{2} \mathrm{O}$, $0.40 ; \mathrm{K}_{2} \mathrm{SO}_{4}, 0.40 ; \mathrm{H}_{3} \mathrm{PO}_{4}\left(88 \%\right.$, w/w), $1.75 ; \mathrm{FeSO}_{4} .7 \mathrm{H}_{2} \mathrm{O}$, $0.025 ; \mathrm{MnSO}_{4} .4 \mathrm{H}_{2} \mathrm{O}, 0.0041 ; \mathrm{ZnSO}_{4} .7 \mathrm{H}_{2} \mathrm{O}, 0.0044$; $\mathrm{CuSO}_{4} .5 \mathrm{H}_{2} \mathrm{O}, 0.00079 ; \mathrm{CaCl}_{2} .2 \mathrm{H}_{2} \mathrm{O}, 0.073 ;\left(\mathrm{NH}_{4}\right)_{2} \mathrm{SO}_{4}$, 3.00; disodium succinate, 5.00. Cultures were maintained at $\mathrm{pH} 7 \cdot 0 \pm 0.1$ and controlled temperature $\left( \pm 0.5^{\circ} \mathrm{C}\right)$ in the range $25-40^{\circ} \mathrm{C}$, with aeration at $0.81 \mathrm{~min}^{-1}$, stirring at 750 r.p.m. and a dilution rate of $0 \cdot 15 \mathrm{~h}^{-1}$. For studies of the effect of growth rate (range $0.05-0.40 \mathrm{~h}^{-1}$ ), cultures were grown at $34^{\circ} \mathrm{C}$ and the succinate concentration of CDM was increased to $10.0 \mathrm{~g} \mathrm{l}^{-1}$. This enhanced concentration was also used in cultures limited by the availability of phosphorus $(88 \%, w / w$, $\left.\mathrm{H}_{3} \mathrm{PO}_{4} ; 0.08 \mathrm{~g} \mathrm{l}^{-1}\right)$, magnesium $\left(\mathrm{MgSO}_{4} .7 \mathrm{H}_{2} \mathrm{O}, 0.10 \mathrm{~g} \mathrm{l}^{-1}\right.$ ) or oxygen (aeration, $0.051 \mathrm{~min}^{-1}$; additional nitrogen, 0.751 $\left.\min ^{-1}\right)$ : in each case, the dilution rate was $0.15 \mathrm{~h}^{-1}$ and the temperature $34^{\circ} \mathrm{C}$. Cultures were monitored continuously for $\mathrm{pH}$, dissolved oxygen tension (Ingold polarographic electrode), $\mathrm{CO}_{2}$ output (IR gas analyser) and optical density $\left(\mathrm{OD}_{540}\right.$; Pharmacia LKB Novaspec II spectrophotometer) to verify the establishment of steady-state growth. Residual succinate was assayed by using succinyl-CoA synthetase (EC 6.2.1.5; Boehringer), ammonium by the method of Chaney \& Marbach (1962) and magnesium by plasma emission spectroscopy (Plasma 40ICP; Perkin-Elmer). Cells were collected from steady-state cultures by centrifugation $(35000 \mathrm{~g}, 30$ $\min , 4^{\circ} \mathrm{C}$ ), washed twice (water), and freeze-dried.

Extraction of lipids. Lipids were extracted by stirring dry cells $(1 \cdot 0-1.4 \mathrm{~g})$ with chloroform/methanol $(2: 1, \mathrm{v} / \mathrm{v} ; 100 \mathrm{ml})$ for $2 \mathrm{~h}$ at room temperature. The suspension was filtered (no. 4 sinter), the insoluble residue was washed with further solvent, and the combined filtrates were rotary-dried. The lipid residue was redissolved in chloroform/methanol and stored at $-20^{\circ} \mathrm{C}$.

Identification of lipids. Phospholipids were identified by (a) TLC, (b) ${ }^{31}$ P NMR spectroscopy (London \& Feigenson, 1979) and (c) high-voltage paper electrophoresis at $\mathrm{pH} \mathrm{5.3} \mathrm{of} \mathrm{the}$ water-soluble products obtained on mild alkaline methanolysis (Wilkinson \& Bell, 1971). Lipids containing ornithine were identified by TLC comparisons and by analysis (vide infra) of the total lipids for ornithine after hydrolysis $(6.1 \mathrm{M}$ $\mathrm{HCl}, 105^{\circ} \mathrm{C}, 4 \mathrm{~h}$ ). The method of Bartlett (1959) was used for the assay of phosphorus, and that of Braunegg et al. (1978) for the assay of poly(3-hydroxybutyrate) (PHB).

Identification of fatty acids. Ester-bound fatty acids were released as methyl esters by mild alkaline methanolysis (Wilkinson \& Bell, 1971). Total fatty acids were obtained by acid hydrolysis $\left(6.1 \mathrm{M} \mathrm{HCl}, 105^{\circ} \mathrm{C}, 4 \mathrm{~h}\right)$, followed by extraction into light petroleum (b.p. $60-80^{\circ} \mathrm{C}$ ) and esterification with ethereal diazomethane or methanolic $\mathrm{HCl}$ (Bryn \& Jantzen, 1982). The methyl esters were identified by GLC and MS.

Chromatographic methods. TLC separations were carried out on silica gel $60 \mathrm{~F}_{254}$ (Merck) with the following solvent systems : A, chloroform/methanol/water $(65: 25: 4$, by vol.); B, chloroform/methanol/acetic acid $(65: 25: 10$, by vol.). Amino lipids were detected with ninhydrin and phospholipids with the reagent of Dittmer \& Lester (1964). For improved chromatography, $\mathrm{PHB}$ was removed from extracts by precipitation with diethyl ether, and non-lipid contaminants by a Folch wash (Duthie \& Patton, 1965). Photodensitometric evaluation of chromatograms was carried out with a Chromoscan 3 (Joyce-Loebl) with a scan length of $10 \mathrm{~cm}$, an aperture of $0.3 \mathrm{~mm}$, a green filter (IFL 2134) for phospholipids and a red filter (IFL 2164) for amino lipids. Replicate scans on the same and duplicate plates were used to obtain mean values.

GLC separations of fatty acid methyl esters were performed at $180^{\circ} \mathrm{C}$ with a fused-silica capillary column $(25 \mathrm{~m} \times 0.2 \mathrm{~mm})$ of BP1 (SGE) in a Megà 5160 chromatograph (Carlo Erba), and hydrogen as the carrier gas. For combined GLC-MS, the chromatograph was coupled to a Finnigan 1020B mass spectrometer. A column ( $25 \mathrm{~m} \times 0.25 \mathrm{~mm})$ of BP20 (SGE) at $145^{\circ} \mathrm{C}$ with nitrogen as the carrier gas and methyl benzoate as the internal standard was used for GLC analyses of methyl 3-hydroxybutyrate. High-performance anion-exchange chromatography with a PAC PA1 column ( $250 \mathrm{~mm} \times 4 \mathrm{~mm}$ ) in a Dionex DM-300 instrument, and pulsed amperometric detection, was used to identify and estimate ornithine. Arginine was used as an internal standard and $23 \mathrm{mM} \mathrm{NaOH}$ containing $7 \mathrm{mM}$ sodium tetraborate as the eluent, giving the following approximate retention times: arginine, $3 \mathrm{~min}$; ornithine, $6 \mathrm{~min}$.

Electron microscopy. Washed cells and media from cultures grown at different temperatures were air-dried on 300-mesh copper grids, negatively stained with $0.5 \%(\mathrm{w} / \mathrm{v})$ phosphotungstic acid and examined by transmission electron microscopy in a JEOL $100 \mathrm{C}$ instrument operated at $80 \mathrm{kV}$.

\section{RESULTS}

In preliminary studies (data not shown), glucose, gluconate and succinate were compared as alternative carbon sources using aerated batch cultures of $B$. cepacia in a phosphate-buffered CDM. Using equal concentrations $\left(10 \mathrm{~g} \mathrm{l}^{-1}\right)$ of each substrate, the maximum specific growth rates $\left(0.36-0.48 \mathrm{~h}^{-1}\right)$, durations of active 
Table 1. Variation in culture density and cellular lipid content with growth temperature for carbon-limited cultures

Cultures were maintained at $\mathrm{pH} 7 \cdot 0$ and dilution rate $0 \cdot 15 \mathrm{~h}^{-1}$. Data are presented for duplicate cultures.

\begin{tabular}{|lccc|}
\hline $\begin{array}{l}\text { Temp. } \\
\left({ }^{\circ} \mathrm{C}\right)\end{array}$ & $\begin{array}{l}\text { Culture } \\
\text { density } \\
\left(\mathrm{OD}_{540}\right)\end{array}$ & $\begin{array}{c}\text { Lipid } \\
\text { content } \\
(\%, \mathbf{w} / \mathbf{w})\end{array}$ & $\begin{array}{c}\text { Lipid } \\
\text { phosphorus } \\
(\%, \mathbf{w} / \mathbf{w})\end{array}$ \\
\hline 25 & $0 \cdot 26 ; 0 \cdot 26$ & $11 \cdot 1 ; 12 \cdot 3$ & $2 \cdot 1 ; 2 \cdot 2$ \\
30 & $0 \cdot 28 ; 0 \cdot 27$ & $13 \cdot 6 ; 13 \cdot 1$ & $1 \cdot 8 ; 1 \cdot 7$ \\
34 & $0 \cdot 30 ; 0 \cdot 30$ & $9 \cdot 7 ; 9 \cdot 8$ & $2 \cdot 0 ; 1 \cdot 9$ \\
37 & $0 \cdot 27 ; 0 \cdot 28$ & $5 \cdot 2 ; 5 \cdot 0$ & $\mathbf{1} \cdot 9 ; 1 \cdot 9$ \\
40 & $0 \cdot 23 ; 0 \cdot 25$ & $5 \cdot 3 ; 5 \cdot 9$ & $2 \cdot 4 ; 2 \cdot 3$ \\
\hline
\end{tabular}

growth $(\sim 20 \mathrm{~h})$ and final culture densities $\left(\mathrm{OD}_{540} \sim\right.$ 1.2) were similar, though the succinate-based culture showed the largest change in $\mathrm{pH}(7 \cdot 0$ to $8 \cdot 8)$. With glucose as carbon source, the shortest lag phase was observed for growth at $34{ }^{\circ} \mathrm{C}$, which was therefore chosen as the standard temperature for chemostat cultures. Initial studies using nitrogen-limited chemostat cultures with glucose as carbon source showed that it was not possible to attain a steady state, as revealed by variations in culture density, $\mathrm{CO}_{2}$ output and residual glucose concentration. Alkali consumption to maintain $\mathrm{pH} 7.0$ was high, and the formation of gluconate and 2ketogluconate (Lessie \& Phibbs, 1984) was confirmed. Further chemostat work was therefore based on succinate-containing CDM, and carbon limitation was routinely used in an attempt to avoid or minimize problems associated with an excess of carbon and energy source (the accumulation of reserve material such as PHB; Dawes, 1992).

\section{Effects of growth temperature on carbon-limited cultures}

Variation of the growth temperature produced visible changes in the organisms. At the highest temperatures ( 37 and $40^{\circ} \mathrm{C}$ ), the cells were a pale cream, but those grown at $34^{\circ} \mathrm{C}$ or below were a dark olive green. Lipid extracts from the latter cells contained a brown pigment which migrated at the solvent front on TLC, but which was not studied further. Cells grown at $25^{\circ} \mathrm{C}$ were short rods (typically about $1.3 \times 0.25 \mu \mathrm{m}$ ) with several polar flagella. As the growth temperature was increased, the cells became somewhat larger and pleomorphic, with fewer flagella: at $40^{\circ} \mathrm{C}$, flagella were absent from the cells and the medium, indicating that their production was switched off. At all growth temperatures, cells contained granules indicative of the storage of PHB. Analysis of lipid extracts confirmed the presence of this polymer (range 9-13\%).

The lipid content of cultures varied markedly, peaking at $30^{\circ} \mathrm{C}$ and tailing off at the higher growth temperatures (Table 1). However, the phosphorus content of the lipids was relatively constant and indi-
Table 2. Distribution of lipid phosphorus and its variation with growth temperature for carbon-limited cultures

Data are expressed as percentages of the total phosphorus as determined by TLC and by ${ }^{31} \mathrm{P}$ NMR spectroscopy (values in parentheses). TLC data are means from duplicate scans of duplicate plates. PE1 incorporates only non-hydroxy acids; in PE2, these are partly replaced by 2 -hydroxy acids.

\begin{tabular}{|lcc|}
\hline $\begin{array}{l}\text { Temp. } \\
\left({ }^{\circ} \mathrm{C}\right)\end{array}$ & $\begin{array}{c}\text { PE1 + PE2 } \\
(\%)\end{array}$ & $\begin{array}{c}\text { DPG }+ \text { PG } \\
(\%)\end{array}$ \\
\hline 25 & $68(69)$ & $32(31)$ \\
30 & $73(60)$ & $27(40)$ \\
34 & $72(65)$ & $28(35)$ \\
37 & $73(60)$ & $27(40)$ \\
40 & $74(58)$ & $26(42)$ \\
\hline
\end{tabular}

cated that phospholipids constituted about $50 \%$ of the total in all extracts. The phospholipids present were DPG, PG, and the two forms of PE: PE1 containing only non-hydroxy acids and PE2 containing 2-hydroxy acids as well. No attempt was made to verify the presence of a minor glycolipid (Yabuuchi et al., 1992), but efforts were made to quantify the relative amounts of the phospholipids by ${ }^{31} \mathrm{P}$ NMR spectroscopy and by TLC (solvent system B) followed by densitometry. In contrast with previous studies (Cox \& Wilkinson, 1989; Galbraith \& Wilkinson, 1991), broad signals on a noisy background were obtained by the NMR method, so that separate PE peaks were not observed and there was partial overlap of those for DPG and PG. Chromatographic resolution on TLC was also incomplete, so the data obtained by both methods (Table 2 ) are only given for lipid pairs. Although quantitative agreement is only modest because of the intrinsic limitations of the methods, it appears that the balance between neutral (PE) and acidic (DPG and PG) lipids was conserved, with the former predominating at all growth temperatures. Visual evaluation of chromatograms and NMR spectra showed that PG was the more abundant acidic phospholipid under all conditions, but the distribution of phosphorus between PG and DPG (TLC) varied from about $1 \cdot 5: 1\left(25^{\circ} \mathrm{C}\right)$ to $2 \cdot 5: 1\left(40^{\circ} \mathrm{C}\right)$.

The relative proportions of PE1 and PE2, as well as those of the two ornithine-containing lipids (OL2 containing 2-hydroxy acids), were determined by TLC (solvent system A) and densitometry (Table 3). The ratio of total PE: total OL remained almost unchanged ( $\sim 2: 1$ ), but the proportions of hydroxylated lipids increased with rising growth temperature, so that the relative amounts of OL1 and OL2 were reversed and the ratio PE1:PE2 fell from $8: 1\left(25^{\circ} \mathrm{C}\right)$ to $2: 1\left(40^{\circ} \mathrm{C}\right)$. Analyses of the total lipids by high-performance anionexchange chromatography showed no major difference or trend in ornithine content (range 5.8-7.8\%).

The major effect of increased growth temperature on the lipid profile of B. cepacia NCTC 10661 is greater 
Table 3. Distribution of amino lipids and its variation with growth temperature for carbon-limited cultures

Data are expressed as percentages of the total colour produced with ninhydrin. Values are means of duplicate scans of duplicate plates, with standard deviations in parentheses. PE1 and PE2 are differentiated by the presence in the latter of 2 hydroxy acids. In OL2, non-hydroxy acids are replaced by 2 hydroxy acids.

\begin{tabular}{|llrrr|}
\hline $\begin{array}{l}\text { Temp. } \\
\left({ }^{\circ} \mathrm{C}\right)\end{array}$ & PE1 $(\%)$ & PE2 $(\%)$ & OL1 $(\%)$ & OL2 $(\%)$ \\
\hline 25 & $63.1(0.6)$ & $7.7(0.2)$ & $19.8(0.3)$ & $9.4(1.1)$ \\
30 & $53.4(1.4)$ & $10.0(1.5)$ & $20.2(0.5)$ & $16.4(1.2)$ \\
34 & $55.4(0.8)$ & $13.4(0.8)$ & $16.5(0.6)$ & $14.7(1.0)$ \\
37 & $47.5(0.4)$ & $18.0(1.8)$ & $12.8(0.9)$ & $21.7(0.6)$ \\
40 & $45.5(0.9)$ & $22.0(2.3)$ & $8.8(1.9)$ & $23.7(0.4)$ \\
\hline
\end{tabular}

production or incorporation of 2-hydroxy acids into zwitterionic lipids (PE and OL). The incorporation is specific to these lipids and, in the case of PE, to the $s n$ 2 position (Yabuuchi et al., 1992). Changes in overall composition of the ester-linked fatty acids (Table 4) should reflect this replacement and any other adaptive responses (e.g. effects on mean chain length, degree of unsaturation or extent of cyclopropanation). Several features were apparent: (a) cyclopropanation was least at $25^{\circ} \mathrm{C}$, and variations with temperature were more pronounced for $19:$ cyc than for $17: \mathrm{cyc}$; (b) the sum of $16: 1$ and $17:$ cyc was almost constant, whereas the sum of $18: 1$ and $19:$ cyc was greatest at low growth temperatures; (c) overall, the proportion of 16:0 showed a modest increase with rising growth temperature. Repeated attempts to monitor temperature-dependent changes in the ester-linked 2-hydroxy acids (mainly 2$\mathrm{OH}-16: 0,2-\mathrm{OH}-16: 1,2-\mathrm{OH}-18: 1$ and $2-\mathrm{OH}-19: \mathrm{cyc})$ were unsuccessful, because of the relatively small, tailing peaks on GLC as previously found for total lipid mixtures (Cox \& Wilkinson, 1989). However, analyses of acid hydrolysates for 3-hydroxyhexadecanoic acid (3$\mathrm{OH}-16: 0)$, the dominant amide-linked acid in OL1 and OL2, showed relatively little variation with temperature (range 3.6-4.7\%), supporting other evidence for an almost constant proportion of total OL.

\section{Effects of growth rate on lipid composition of carbon-limited cultures}

For organisms grown at $34^{\circ} \mathrm{C}$ with carbon as the limiting nutrient, growth rate affected both lipid content and distribution. The lipid content was highest $(9.8 \%)$ at the dilution rate of $0 \cdot 15 \mathrm{~h}^{-1}$ and least $(3 \cdot 2 \%)$ at the rate of $0.05 \mathrm{~h}^{-1}$. As determined by TLC, the proportion of total $\mathrm{PE}$ did not change significantly with growth rate (range 70-78\%), but the ratio of DPG:PG was highest $(2 \cdot 3: 1)$ in slow-growing cells (dilution rate $0.05 \mathrm{~h}^{-1}$ ) and lowest $(0.6: 1)$ in fast-growing cells (dilution rate 0.40 $\left.\mathrm{h}^{-1}\right)$. The PE: OL ratio also varied with growth rate, rising from $1 \cdot 6: 1$ (dilution rate $0.05 \mathrm{~h}^{-1}$ ) to $3: 1$ (dilution rate $0.40 \mathrm{~h}^{-1}$ ). The proportions of OL1 and OL2 were similar at all growth rates and the ratio PE1:PE2 was about $4: 1$ except at the highest growth rate $(9: 1$ at the dilution rate of $\left.0.40 \mathrm{~h}^{-1}\right)$. Variations in the composition of ester-linked, non-hydroxy acids are shown in Table 5. The most striking trend is the progressive decline in cyclopropanation of the monoenoic acids as the growth rate was increased.

\section{Effects on lipid composition of the growth-limiting nutrient}

When cells were grown under standard conditions $\left(34^{\circ} \mathrm{C}\right.$, dilution rate $\left.0 \cdot 15 \mathrm{~h}^{-1}\right)$ but with either magnesium or oxygen as the limiting nutrient, the polar lipid and

Table 4. Ester-linked, non-hydroxy fatty acids in the total lipids and their variation with growth temperature for carbon-limited cultures

Data are expressed as percentages of the total peak area on GLC of the methyl esters obtained by mild alkaline methanolysis. Values are means from duplicate chromatograms and duplicate experiments, with standard deviations in parentheses.

\begin{tabular}{|c|c|c|c|c|c|}
\hline \multirow[t]{2}{*}{ Fatty acid* } & \multicolumn{5}{|c|}{ Growth temperature $\left({ }^{\circ} \mathrm{C}\right)$} \\
\hline & 25 & 30 & 34 & 37 & 40 \\
\hline $14: 0$ & $0.6(0.0)$ & $1 \cdot 0(0 \cdot 1)$ & Trace & Trace & Trace \\
\hline $16: 0$ & $16.4(0.6)$ & $15 \cdot 7(0.5)$ & $19 \cdot 1(0.9)$ & $22.7(0.4)$ & $21 \cdot 1(0.5)$ \\
\hline $16: 1$ & $19.6(0.9)$ & $13 \cdot 2(1 \cdot 5)$ & $15 \cdot 8(1.0)$ & $14 \cdot 1(0 \cdot 2)$ & $14.3(0.7)$ \\
\hline $17:$ cyc & $10.2(0.6)$ & $18 \cdot 6(2 \cdot 3)$ & $18.3(0.8)$ & $20.6(1.2)$ & $19.5(0.3)$ \\
\hline $18: 0$ & $3.6(0.4)$ & $2.6(0.4)$ & $2.4(0.4)$ & $2.1(0.7)$ & $3.8(0.5)$ \\
\hline $18: 1$ & $46.6(0.6)$ & $30.6(0.5)$ & $33 \cdot 2(2 \cdot 0)$ & $33.5(0 \cdot 1)$ & $32.0(0 \cdot 1)$ \\
\hline $19:$ cyc & $3 \cdot 0(0 \cdot 1)$ & $18 \cdot 3(1 \cdot 2)$ & $11 \cdot 2(3 \cdot 3)$ & $7.0(0.6)$ & $9.3(0.1)$ \\
\hline
\end{tabular}

* Shorthand designation: the number before the colon indicates the total number of carbon atoms, the number after the colon indicates the number of double bonds, and cyc indicates the presence of a cyclopropane ring. 
Table 5. Variations with growth rate of ester-linked, non-hydroxy fatty acids in the lipids of carbon-limited cultures

Data are expressed as percentages of the total peak area on GLC of the methyl esters obtained by mild alkaline methanolysis. Values are the means from duplicate chromatograms, with standard deviations in parentheses. See Table 4 for the fatty acid shorthand.

\begin{tabular}{|c|c|c|c|c|}
\hline \multirow[t]{2}{*}{ Fatty acid } & \multicolumn{4}{|c|}{ Dilution rate $\left(h^{-1}\right)$} \\
\hline & 0.05 & $0 \cdot 15$ & $0 \cdot 20$ & 0.40 \\
\hline $14: 0$ & 0 & Trace & Trace & 0 \\
\hline $16: 0$ & $33.8(0.8)$ & $20 \cdot 8(1 \cdot 7)$ & $20.9(0.6)$ & $30 \cdot 3\langle 0.5\rangle$ \\
\hline $16: 1$ & $8.5(0.9)$ & $13.9(0.4)$ & $18 \cdot 6(1 \cdot 3)$ & $27 \cdot 0(0 \cdot 2)$ \\
\hline $17:$ cyc & $23.3(0.6)$ & $19 \cdot 8(0 \cdot 8)$ & $16 \cdot 6(0 \cdot 8)$ & $4.5(0.3)$ \\
\hline $18: 0$ & Trace & $2 \cdot 4\langle 1 \cdot 1)$ & $1.8(1.6)$ & Trace \\
\hline $18: 1$ & $23.5(0 \cdot 3)$ & $33.6(0.7)$ & $37.6(0.3)$ & $38.2(1.4)$ \\
\hline $19:$ cyc & $10.9(0.7)$ & $9.5(0.6)$ & $4 \cdot 4(0.4)$ & 0 \\
\hline
\end{tabular}

fatty acid profiles were very similar to those described above for carbon limitation (data not shown). However, when phosphorus was the growth-limiting nutrient, OL1 and OL2 were the only polar lipids detected and 3$\mathrm{OH}-16: 0$ was the major fatty acid in an acid hydrolysate ( $34 \%$ of the total).

\section{DISCUSSION}

\section{Profiles of polar lipids}

Although phospholipid profiles constituted from PE, PG and DPG are commonplace among Gram-negative bacteria, and OL is also rather often encountered (Wilkinson, 1988), the occurrence of two forms each of $\mathrm{PE}$ and $\mathrm{OL}$ appears to be unique to Burkbolderia spp. (Galbraith \& Wilkinson, 1991; Yabuuchi et al., 1992). One anomaly (Yabuuchi et al., 1995) is posed by Burkbolderia andropogonis, which contains both forms of PE but neither form of OL, thus resembling Ralstonia spp. in this respect (Galbraith \& Wilkinson, 1991; Yabuuchi et al., 1992, 1995). Other bacteria known or suspected to produce two forms of PE analogous to PE1 and PE2 include some actinomycetes (Kawanami et al., 1969; Yano et al., 1970; Pramanik et al., 1990; Hoischen et al., 1997) and myxobacteria (Yamanaka et al., 1988). Non-hydroxy and hydroxy forms of OL comparable with OL1 and OL2 are reported to occur in Flavobacterium spp. (Kawai et al., 1988a; Asselineau et al., 1988) and at least some Cytophaga strains (Pitta et al., 1989; Kawazoe et al., 1992). Lipids of the general structure 1 with only 2-hydroxy fatty acids in ester linkage (like OL2) are present in Thiobacillus thiooxidans (Knoche \& Shively, 1972) and Gluconobacter cerinus (Tahara et al., 1976).

\section{Effect of phosphorus-limited growth}

The present study has shown that for B. cepacia, at least, the unusual profile of polar lipids is a rather stable phenotype. Only under phosphorus-limited growth is the profile drastically changed, with total replacement of PE by OL. Similar effects of phosphorus deprivation have been described for Pseudomonas fluorescens (Minnikin \& Abdolrahimzadeh, 1974; Dorrer \& Teuber, 1977) and Rhodobacter sphaeroides (Benning et al., 1995), and probably apply also to Shewanella putrefaciens (Pseudomonas rubescens; Wilkinson, 1972) and many other OL-producing species. However, a lowphosphate medium had no significant effect on Paracoccus denitrificans (Wilkinson et al., 1982) whereas the proportion of OL was enhanced by a deficiency of divalent cations (Wee \& Wilkinson, 1988). Whether the simultaneous loss of PG and DPG in phosphorus-limited cultures of $B$. cepacia was compensated for by the production of an acidic glycolipid [as described for Brevundimonas (Pseudomonas) diminuta (Minnikin et al., 1974) and R. sphaeroides (Benning et al., 1995)] was not established by this study, although the detection of an uncharacterized glycolipid in B. cepacia (Yabuuchi et al., 1992) raises that possibility. A glycolipid in Burkholderia pseudomallei with similar low mobility on TLC contains both 2-hydroxy and non-hydroxy acids (Phung et al., 1995a, b).

\section{Effects of growth temperature}

Many studies of the effects of growth temperature on bacterial lipid composition have been carried out (Ratledge \& Wilkinson, 1988; Suutari \& Laakso, 1994), but in most cases the inferences are, to some degree, compromised by failure to disentangle possible effects of growth temperature from those of growth rate, in particular. Thus opportunities for direct comparison of the present results with those of previous studies are limited. The marked dependence on growth temperature of cellular lipid content for carbon-limited cultures of $B$. cepacia (Table 1) was not observed for similar cultures of $P$. fluorescens (Gill, 1975) and other psychrotrophic 
pseudomonads (Bhakoo \& Herbert, 1980), nor for batch cultures of psychrotrophic pseudomonads (Cullen et al., 1971; Wada et al., 1987) and Yersinia enterocolitica (Nagamachi et al., 1991), for example. However, trends towards higher lipid contents at lower growth temperatures have been recorded in some studies of $Y$. enterocolitica (Abbas \& Card, 1980) and psychrophilic, marine Vibrio strains (Bhakoo \& Herbert, 1979). In the case of $B$. cepacia, the variations in cellular lipid are apparently not attributable to variable production of $\mathrm{PHB}$, nor to major changes in the relative proportions of polar and apolar lipids, but the lower lipid content of cells grown at higher temperatures may partly be explained by their greater size.

As shown (Tables 2 and 3), growth temperature has no significant effect on the ratios of total PE:total OL:PG + DPG in B. cepacia. Similar stability of the polar lipid composition has been described for other Gram-negative bacteria, including carbon-limited chemostat cultures of psychrotrophic pseudomonads (Bhakoo \& Herbert, 1980), and also batch-grown Escherichia coli (Haest et al., 1969), P. fluorescens (Cullen et al., 1971), another psychrotrophic pseudomonad (Wada et al., 1987) and Y. enterocolitica (Abbas \& Card, 1980; Tsuchiya et al., 1987; Nagamachi et al., 1991). A rise in PG:DPG ratio with increasing growth temperature, as found for carbon-limited cultures of $B$. cepacia, was also reported for nitrogen-limited chemostat cultures of $P$. fluorescens, but the proportions of both acidic phospholipids increased (relative to PE) with temperature when the latter organism was grown under carbon-limiting conditions (Gill, 1975). More complex fluctuations in phospholipid profiles have been described for various halophilic and psychrophilic organisms (Bhakoo \& Herbert, 1979; Ohno et al., 1979; Adams \& Russell, 1992).

The aspect of bacterial lipids most extensively studied in relation to thermal adaptation is fatty acid composition (Suutari \& Laakso, 1994). The cellular response to reduced growth temperature, which may be an increase in the proportion of unsaturated fatty acids, a decrease of mean chain length, an increase in the extent or change in location of branching, or a decrease in cyclopropanation of monoenoic acids (Russell, 1984), is normally interpreted as a mechanism for the preservation of membrane fluidity (homoviscous adaptation; Sinensky, 1974), although other explanations may be invoked (Hazel, 1995). The present results for non-hydroxy acids in B. cepacia (Table 4) are broadly consistent with those for other, typical Gram-negative bacteria, but the most striking trend is the increased production and specific incorporation of 2-hydroxy acids into $\mathrm{PE}$ and $\mathrm{OL}$ with rising growth temperature. Relatively little is known about the formation and lipid incorporation of 2-hydroxy acids in bacteria, although characteristics of the $\alpha$-hydroxylase in Sphingomonas paucimobilis, an organism producing glycosphingolipids rather than lipopolysaccharide (Kawasaki et al., 1994), have been determined (Matsunaga et al., 1994, 1996). The effect of a 2-hydroxy group on the gel-to- liquid crystalline phase transition temperature may depend on the parent lipid and its environment, although 2-hydroxylation of a glycosphingolipid in a bilayer of phosphatidylcholine appeared to disrupt packing of the acyl chains (Singh et al., 1992). The consequences for membrane fluidity and thermal transition of the increased hydroxylation of PE and OL in B. cepacia at higher growth temperatures have yet to be determined.

\section{Effects of growth rate}

Change of growth rate at constant temperature $\left(34^{\circ} \mathrm{C}\right)$ with carbon as the limiting nutrient affected both the polar lipid and the fatty acid composition of B. cepacia, as well as the total lipid content. In contrast, little or no change in lipid content of carbon-limited cultures was found for E. coli (Damoglou \& Dawes, 1968; Calcott \& Petty, 1980) or P. aeruginosa (Gilbert \& Brown, 1978). Also, the DPG:PG ratio rose markedly with increasing growth rate for E. coli (Calcott \& Petty, 1980), and slightly for $P$. aeruginosa (Gilbert \& Brown, 1978), but fell for B. cepacia. The accumulation of DPG by Gramnegative bacteria is often observed as the growth rate declines and cells enter the stationary phase in batch culture (Wilkinson, 1988). In earlier studies using batch cultures of B. cepacia NCTC 10661 (equivalent to ATCC 17759 and the O7 reference strain), the PG content was reported as little or none (Cox \& Wilkinson, 1989), minor (DPG:PG ratio about $6: 1$; Kawai et al., 1988b) or the sole acidic phospholipid (Anwar et al., 1983a). The last result was also reported for the type strain (Yabuuchi et al., 1992). Low growth rates in chemostat cultures and ageing of batch cultures also often promote the conversion of monoenoic acids into their cyclopropane derivatives (Gill \& Suisted, 1978; Leach et al., 1997), as found for B. cepacia (Table 5), although the contrary effect was noted in one study of $E$. coli (Arneborg et al., 1993). Growth rate and other cultural parameters have been shown to influence potential virulence factors of $B$. cepacia and sensitivity of the organism to antibacterial action (Anwar et al., 1983b; Cozens \& Brown, 1983; McKenney et al., 1994; McKenney \& Allison, 1995, 1997), and the present study shows that variation of the lipid profile also needs to be considered in these contexts.

\section{ACKNOWLEDGEMENTS}

We thank the Medical Research Council for a project grant in support of this study. Technical assistance was provided by Ms J. Halder (electron microscopy), Mr R. Knight (plasma emission spectroscopy) and $\mathrm{Mr} \mathrm{A}$. D. Roberts (mass spectrometry).

\section{REFERENCES}

Abbas, C. A. \& Card, G. L. (1980). The relationships between growth temperature, fatty acid composition and the physical state and fluidity of membrane lipids in Yersinia enterocolitica. Biochim Biophys Acta 602, 469-476.

Adams, R. L. \& Russell, N. J. (1992). Interactive effects of salt 
concentration and temperature on growth and lipid composition in the moderately halophilic bacterium Vibrio costicola. Can J Microbiol 38, 823-827.

Anwar, H., Brown, M. R. W., Cozens, R. M. \& Lambert, P. A. (1983a). Isolation and characterization of the outer and cytoplasmic membranes of Pseudomonas cepacia. J Gen Microbiol 129, 499-507.

Anwar, H., Brown, M. R. W. \& Lambert, P. A. (1983b). Effect of nutrient depletion on sensitivity of Pseudomonas cepacia to phagocytosis and serum bactericidal activity at different temperatures. J Gen Microbiol 129, 2021-2027.

Arneborg, N., Steen Salskov-lversen, A. \& Mathiasen, T. E. (1993). The effect of growth rate and other growth conditions on the lipid composition of Escherichia coli. Appl Microbiol Biotechnol 39, 353-357.

Asselineau, J., Pichinoty, F., Promé, D. \& Promé, J.-C. (1988). Composition des lipides complexes de Flavobacterium meningosepticum. Ann Microbiol (Paris) 139, 159-170.

Bartlett, G. R. (1959). Phosphorus assay in column chromatography. J Biol Chem 234, 466-468.

Benning, C., Huang, Z.-H. \& Gage, D. A. (1995). Accumulation of a novel glycolipid and a betaine lipid in cells of Rhodobacter sphaeroides grown under phosphate limitation. Arch Biochem Biophys 317, 103-111.

Bhakoo, M. \& Herbert, R. A. (1979). The effects of temperature on the fatty acid and phospholipid composition of four obligately psychrophilic Vibrio spp. Arch Microbiol 121, 121-127.

Bhakoo, M. \& Herbert, R. A. (1980). Fatty acid and phospholipid composition of five psychrotrophic Pseudomonas spp. grown at different temperatures. Arch Microbiol 126, 51-55.

Braunegg, G., Sonnleitner, B. \& Lafferty, R. M. (1978). A rapid gas chromatographic method for the determination of poly- $\beta$ hydroxybutyric acid in microbial biomass. Eur J Appl Microbiol Biotechnol 6, 29-37.

Bryn, K. \& Jantzen, E. (1982). Analysis of lipopolysaccharides by methanolysis, trifluoroacetylation, and gas chromatography on a fused-silica capillary column. J Chromatogr 240, 405-413.

Calcott, P. H. \& Petty, R. S. (1980). Phenotypic variability of lipids of Escherichia coli grown in chemostat culture. FEMS Microbiol Lett 7, 23-27.

Chaney, A. L. \& Marbach, E. P. (1962). Modified reagents for determination of urea and ammonia. Clin Chem 8, 130-132.

Cox, A. D. \& Wilkinson, S. G. (1989). Polar lipids and fatty acids of Pseudomonas cepacia. Biochim Biophys Acta 1001, 60-67.

Cozens, R. M. \& Brown, M. R. W. (1983). Effect of nutrient depletion on the sensitivity of Pseudomonas cepacia to antimicrobial agents. J Pharm Sci 72, 1363-1365.

Cullen, J., Phillips, M. C. \& Shipley, G. G. (1971). The effects of temperature on the composition and physical properties of the lipids of Pseudomonas fluorescens. Biochem J 125, 733-742.

Damoglou, A. P. \& Dawes, E. A. (1968). Studies on the lipid content and phosphate requirement of glucose- and acetategrown Escherichia coli. Biochem J 110, 775-781.

Dawes, E. A. (1992). Storage polymers in prokaryotes. Symp Soc Gen Microbiol 47, 81-122.

Dittmer, J. C. \& Lester, R. L. (1964). A simple, specific spray for the detection of phospholipids on thin-layer chromatograms. J Lipid Res 5, 126-127.

Dorrer, E. \& Teuber, M. (1977). Induction of polymyxin resistance in Pseudomonas fluorescens by phosphate limitation. Arch Microbiol 114, 87-89.
Duthie, A. H. \& Patton, S. (1965). Purification of phospholipids removed from thin-layer chromatograms for infrared spectral analysis. J Lipid Res 6, 320-322.

Galbraith, L. \& Wilkinson, S. G. (1991). Polar lipids and fatty acids of Pseudomonas caryophylli, Pseudomonas gladioli and Pseudomonas pickettii. J Gen Microbiol 137, 197-202.

Gilbert, P. \& Brown, M. R. W. (1978). Influence of growth rate and nutrient limitation on the gross cellular composition of Pseudomonas aeruginosa and its resistance to 3- and 4-chlorophenol. J Bacteriol 133, 1066-1072.

Gill, C. O. (1975). Effect of growth temperature on the lipids of Pseudomonas fuorescens. J Gen Microbiol 89, 293-298.

Gill, C. O. \& Suisted, J. R. (1978). The effects of temperature and growth rate on the proportion of unsaturated fatty acids in bacterial lipids. J Gen Microbiol 104, 31-36.

Govan, J. R. W. \& Deretic, V. (1996). Microbial pathogenesis in cystic fibrosis: mucoid Pseudomonas aeruginosa and Burkholderia cepacia. Microbiol Rev 60, 539-574.

Govan, J. R. W., Hughes, J. E. \& Vandamme, P. (1996). Burkholderia cepacia: medical, taxonomic and ecological issues. J Med Microbiol 45, 395-407.

Haest, C. W. M., De Gier, J. \& van Deenen, L. L. M. (1969). Changes in the chemical and the barrier properties of the membrane lipids of $E$. coli by variation of the temperature of growth. Chem Phys Lipids 3, 413-417.

Hazel, J. R. (1995). Thermal adaptation in biological membranes: is homeoviscous adaptation the explanation? Annu Rev Pbysiol 57, $19-42$.

Hoischen, C., Gura, K., Luge, C. \& Gumpert, J. (1997). Lipid and fatty acid composition of cytoplasmic membranes from Streptomyces bygroscopicus and its stable protoplast-type L form. J Bacteriol 179, 3430-3436.

Kato, H. \& Goto, N. (1997). Adjuvanticity of an ornithinecontaining lipid of Flavobacterium meningosepticum as a candidate vaccine adjuvant. Microbiol Immunol 41, 101-106.

Kawai, Y. \& Akagawa, K. (1989). Macrophage activation by an ornithine-containing lipid or a serine-containing lipid. Infect Immun 57, 2086-2091.

Kawai, Y. \& Yano, I. (1983). Ornithine-containing lipid of Bordetella pertussis, a new kind of hemagglutinin. Eur J Biochem 136, 531-538.

Kawai, Y., Yano, I. \& Kaneda, K. (1988a). Various kinds of lipoamino acids including a novel serine-containing lipid in an opportunistic pathogen Flavobacterium. Their structures and biological activities on erythrocytes. Eur J Biochem 171, 73-80.

Kawai, Y., Yano, I., Kaneda, K. \& Yabuuchi, E. (1988b). Ornithinecontaining lipids of some Pseudomonas species. Eur J Biochem $175,633-641$.

Kawai, Y., Takasuka, N., Akagawa, K. \& Naito, S. (1996). Hypothermic response of mice to ornithine-containing lipids and to endotoxin. Infect Immun 64, 2101-2105.

Kawanami, J., Kimura, A., Nakagawa, Y. \& Otsuka, H. (1969). Lipids of Streptomyces sioyaensis. V. On the 2-hydroxy-13methyltetradecanoic acid from phosphatidylethanolamine. Chem Phys Lipids 3, 29-38.

Kawasaki, S., Moriguchi, R., Sekiya, K., Nakai, T., Ono, E., Kume, K. \& Kawahara, K. (1994). The cell envelope structure of the lipopolysaccharide-lacking gram-negative bacterium Sphingomonas paucimobilis. J Bacteriol 176, 284-290.

Kawazoe, R., Monde, K., Reichardt, W. \& Okuyama, H. (1992). Lipoamino acids and sulfonolipids in Cytophaga johnsonae 
Stanier strain C21 and six related species of Cytophaga. Arch Microbiol 158, 171-175.

Knoche, H. W. \& Shively, J. M. (1972). The structure of an ornithine-containing lipid from Thiobacillus thiooxidans. J Biol Chem 247, 170-178.

Leach, S., Harvey, P. \& Wait, R. (1997). Changes with growth rate in the membrane lipid composition of and amino acid utilization by continuous cultures of Campylobacter jejuni. J Appl Microbiol $82,631-640$.

Lessie, T. G. \& Phibbs, P. V. (1984). Alternative pathways of carbohydrate utilization in pseudomonads. Annu Rev Microbiol 38, 359-387.

London, E. \& Feigenson, G. W. (1979). Phosphorus NMR analysis of phospholipids in detergents. J Lipid Res 20, 408-412.

McKenney, D. \& Allison, D. G. (1995). Effects of growth rate and nutrient limitation on virulence factor production in Burkbolderia cepacia. J Bacteriol 177, 4140-4143.

McKenney, D. \& Allison, D. G. (1997). Influence of growth rate and nutrient limitation on susceptibility of Burkbolderia cepacia to ciprofloxacin and tobramycin. J Antimicrob Chemother 40, 414-417.

McKenney, D., Willcock, L., Trueman, P. A. \& Allison, D. G. (1994). Effect of sub-MIC antibiotics on the cell surface and extracellular virulence determinants of Pseudomonas cepacia. J Appl Bacteriol 76, 190-195.

Matsunaga, I., Kusunose, E., Yano, I. \& Ichihara, K. (1994). Separation and partial characterisation of soluble fatty acid $\alpha$ hydroxylase from Sphingomonas paucimobilis. Biochem Biophys Res Commun 201, 1554-1560.

Matsunaga, I., Yamada, M., Kusunose, E., Nishiuchi, Y., Yano, I. \& Ichihara, K. (1996). Direct involvement of hydrogen peroxide in bacterial $\alpha$-hydroxylation of fatty acid. FEBS Lett 386, 252-254.

Minnikin, D. E. \& Abdolrahimzadeh, H. (1974). The replacement of phosphatidylethanolamine and acidic phospholipids by an ornithine-amide lipid and a minor phosphorus-free lipid in Pseudomonas fluorescens NCMB 129. FEBS Lett 43, 257-260.

Minnikin, D. E., Abdolrahimzadeh, H. \& Baddiley, J. (1974). Replacement of acidic phospholipids by acidic glycolipids in Pseudomonas diminuta. Nature 249, 268-269.

Nagamachi, E., Shibuya, S., Hirae, Y., Matsushita, O., Tomochika, K. \& Kanemasa, Y. (1991). Adaptational changes of fatty acid composition and the physical state of membrane lipids following the change of growth temperature in Yersinia enterocolitica. Microbiol Immunol 35, 1085-1093.

Nelson, J. W., Butler, S. L., Krieg, D. \& Govan, J. R. W. (1994). Virulence factors of Burkbolderia cepacia. FEMS Immunol Med Microbiol 8, 89-98.

Ohno, Y., Yano, I. \& Masui, M. (1979). Effect of $\mathrm{NaCl}$ concentration and temperature on the phospholipid and fatty acid compositions of a moderately halophilic bacterium, Pseudomonas halosaccharolytica. J Biochem (Tokyo) 85, 413-421.

Phung, L. V., Chi, T. T. B., Hotta, H., Yabuuchi, E. \& Yano, I. (1995a). Cellular lipid and fatty acid compositions of Burkbolderia pseudomallei strains isolated from human and environment in Viet Nam. Microbiol Immunol 39, 105-116.

Phung, L. V., Han, Y., Oka, S., Hotta, H., Smith, M. D., Theeparakun, P., Yabuuchi, E. \& Yano, I. (1995b). Enzyme-linked immunosorbent assay (ELISA) using a glycolipid antigen for the serodiagnosis of melioidosis. FEMS Immunol Med Microbiol 12, 259-264.

Pitta, T. P., Leadbetter, E. R. \& Godchaux, W. (1989). Increase of ornithine amino lipid content in a sulfonolipid-deficient mutant of Cytophaga jobnsonae. J Bacteriol 171, 952-957.

Pramanik, B. N., Zechman, J. M., Das, P. R. \& Bartner, P. L. (1990). Bacterial phospholipid analysis by fast atom bombardment mass spectrometry. Biomed Environ Mass Spectrom 19, 164-170.

Ratledge, C. \& Wilkinson, S. G. (editors) (1988). Microbial Lipids, vol. 1. London: Academic Press.

Russell, N. J. (1984). Mechanisms of thermal adaptation in bacteria: blueprints for survival. Trends Biochem Sci 9, 108-112.

Sinensky, M. (1974). Homeoviscous adaptation - a homeostatic process that regulates viscosity of membrane lipids in Escherichia coli. Proc Natl Acad Sci USA 71, 522-525.

Singh, D., Jarrell, H. C., Florio, E., Fenske, D. B. \& Grant, C. W. M. (1992). Effects of fatty acid alpha-hydroxylation on glycosphingolipid properties in phosphatidylcholine bilayers. Biochim Biopbys Acta 1103, 268-274.

Suutari, M. \& Laakso, S. (1994). Microbial fatty acids and thermal adaptation. Crit Rev Microbiol 20, 285-328.

Tahara, Y., Kameda, M., Yamada, Y. \& Kondo, K. (1976). An ornithine-containing lipid isolated from Gluconobacter cerinus. Biochim Biophys Acta 450, 225-230.

Tsuchiya, H., Sato, M., Kanematsu, N., Kato, M., Hoshino, Y., Takagi, N. \& Namikawa, I. (1987). Temperature-dependent changes in phospholipid and fatty acid composition and membrane lipid fluidity of Yersinia enterocolitica. Lett Appl Microbiol 5, 15-18.

Wada, M., Fukunaga, N. \& Sasaki, S. (1987). Effect of growth temperature on phospholipid and fatty acid compositions in a psychrotrophic bacterium, Pseudomonas sp. strain E-3. Plant Cell Physiol 28, 1209-1217.

Wee, S. \& Wilkinson, B. J. (1988). Increased outer membrane ornithine-containing lipid and lysozyme penetrability of Paracoccus denitrificans grown in a complex medium deficient in divalent cations. J Bacteriol 170, 3283-3286.

Wilkinson, B. J., Sment, K. A. \& Mayberry, W. R. (1982) Occurrence, localization, and possible significance of an ornithine-containing lipid in Paracoccus denitrificans. Arch Microbiol 131, 338-343.

Wilkinson, S. G. (1972). Composition and structure of the ornithine-containing lipid from Pseudomonas rubescens. Biochim Biophys Acta 270, 1-17.

Wilkinson, S. G. (1988). Gram-negative bacteria. In Microbial Lipids, vol. 1, pp. 299-488. Edited by C. Ratledge \& S. G. Wilkinson. London: Academic Press.

Wilkinson, S. G. \& Bell, M. E. (1971). The phosphoglucolipid from Pseudomonas diminuta. Biochim Biophys Acta 248, 293-299.

Wilkinson, S. G. \& Pitt, T. L. (1995a). Burkbolderia (Pseudomonas) cepacia: surface chemistry and typing methods. Rev Med Microbiol 6, 1-9.

Wilkinson, S. G. \& Pitt, T. L. (1995b). Burkbolderia (Pseudomonas) cepacia: pathogenicity and resistance. Rev Med Microbiol 6, 10-17.

Yabuuchi, E., Kosako, Y., Oyaizu, H., Yano, I., Hotta, H., Hashimoto, Y., Ezaki, T. \& Arakawa, M. (1992). Proposal of Burkbolderia gen. nov. and transfer of seven species of the genus Pseudomonas homology group II to the new genus, with the type species Burkbolderia cepacia (Palleroni and Holmes 1981) comb. nov. Microbiol Immunol 36, 1251-1275.

Yabuuchi, E., Kosako, Y., Yano, l., Hotta, H. \& Nishiuchi, Y. (1995). Transfer of two Burkholderia and an Alcaligenes species to Ralstonia gen. nov.: proposal of Ralstonia pickettii (Ralston, 
Palleroni and Doudoroff 1973) comb. nov., Ralstonia solanacearum (Smith 1896) comb. nov. and Ralstonia eutropha (Davis 1969) comb. nov. Microbiol Immunol 39, 897-904.

Yamanaka, S., Fudo, R., Kawaguchi, A. \& Komagata, K. (1988).

Taxonomic significance of hydroxy fatty acids in myxobacteria with special reference to 2-hydroxy fatty acids in phospholipids. $J$ Gen Appl Microbiol 34, 57-66.
Yano, I., Furukawa, Y. \& Kusunose, M. (1970). $\alpha$-Hydroxy fatty acid-containing phospholipids of Nocardia leishmanii. Biochim Biophys Acta 202, 189-191.

Received 19 January 1998; revised 13 March 1998; accepted 26 March 1998. 